\title{
Development of monoclonal-antibody-ELISA and -DIP-STICK immunoassays for Penicillium islandicum in rice grains
}

\author{
F. M. Dewey, ${ }^{1 *}$ M. M. MacDonald, ${ }^{1} \uparrow$ S. I. Phillips ${ }^{2}$ and R. A. Priestley ${ }^{1}$ \\ ${ }^{1}$ Department of Plant Sciences, University of Oxford, South Parks Road, Oxford OXI 3RA, UK \\ 2 ODNRI, Central Avenue, Chatham Maritime, Chatham, Kent ME4 4TB, UK
}

(Received 8 December 1989; accepted 2 January 1990)

\begin{abstract}
Monoclonal antibodies (mAbs) were raised against Penicillium islandicum, a fungus commonly isolated from stored rice grains in South-East Asia. Mice were immunized by a direct, simple method; fresh cell-free surface washings from a solid agar slant culture were injected directly into the peritoneum without prior concentration. Hybridoma supernatants were screened by ELISA. Most of the mAbs raised cross-reacted with other storage fungi and/or uninfected rice grains but three were species-specific. One of these, PI01, was used to develop ELISA and DIP-STICK assays for the detection of $P$. islandicum in individual grains. All inoculated grains and approximately $\mathbf{9 0} \%$ of grains in natural infected samples from Indonesia tested positively, by ELISA, for $P$. islandicum. This result and those obtained for discoloured grains from both Indonesia and the Philippines, $32 \%$ and $14 \%$ respectively, are higher than those obtained by direct plating of surface-sterilized grains. Heat and periodate treatment of the PI01 antigen and binding on Western blots indicate that it is a glycoprotein of $M_{r}>90000$. Hyphae of all ages stained uniformly by immunofluorescence using the PI01 antibody but mature conidia stained only weakly.
\end{abstract}

\section{Introduction}

Many species of Penicillium are known to produce mycotoxins. Penicillium islandicum, a cause of one type of yellowing in stored milled rice, has been associated with toxicity, particularly in South-East Asia (Tsunoda, 1953). Symptoms include liver lesions, cirrhosis and primary liver cancer (Moreau, 1979). The detection of toxigenic species is therefore of considerable importance but the identification of Penicillium spp. requires expertise and standard isolation procedures that are often unsatisfactory (see Pitt, 1979). A rapid assay such as an enzyme-linked immunosorbent assay (ELISA) or DOT-BLOT immunoassay is needed that would specifically differentiate $P$. islandicum from other species of Penicillium or Aspergillus. Notermans et al. (1987) developed a relatively specific antiserum that recognized only species of Penicillium and Aspergillus but apparently

+ Present address: School of Biochemistry, University of Melbourne, Parkville, Victoria 3052, Australia.

Abbreviations: FBS, foetal bovine serum; HAZA, hypoxanthine azaserine; $\mathrm{mAb}$, monoclonal antibody; PBS, phosphate-buffered saline; PBST, PBS with $0.05 \%$ Tween 20; PVDF, polyvinylidene difluoride; TBS, Tris-buffered saline; TCMC, tissue culture medium control (contains 5\% FBS). no-one has yet developed antiserum or monoclonal antibodies (mAbs) that will detect only one species of Penicillium and differentiate it from all others. However, because it has now been shown that it is possible to raise mAbs of varying specificity against fungi (Dewey et al., $1989 a, b)$ and use these to develop immunoassays, we decided to try to raise mAbs specific for $P$. islandicum.

The present communication describes a method for the specific detection of $\boldsymbol{P}$. islandicum in rice grains by ELISA and DIP-STICK immunoassays using mAbs raised against surface washings of the fungus.

\section{Methods}

Rice samples, fungal cultures and preparation of the immunogen. Samples of white milled rice, both naturally infected and non-infected 'good' rice, were obtained from Indonesia and the Philippines. Inoculation of rice grains with fungi in the laboratory was done with commercial milled white rice samples, purchased in the UK, and 'good' samples from Indonesia and the Philippines.

All cultures of fungi (Table 1) were originally isolated by a direct plating technique (Phillips et al., 1988) from naturally infected grains collected from dry stored rough rice from Indonesia. Isolates were maintained in pure culture on agar slants.

Cultures (5-d-old) of $P$. islandicum, grown on yeast/starch agar slants (YSA) (Cooney \& Emerson, 1964) at $30^{\circ} \mathrm{C}$, were washed briefly with $1 \mathrm{ml}$ phosphate-buffered saline (PBS; $0.8 \% \mathrm{NaCl}, 0.02 \% \mathrm{KCl}, 0.115 \%$ 
Table 1. Details of fungal cultures and growth conditions

\begin{tabular}{|c|c|c|c|c|c|}
\hline \multirow[b]{2}{*}{ Culture } & \multirow[b]{2}{*}{$\begin{array}{l}\text { Isolate } \\
\text { number }\end{array}$} & \multirow[b]{2}{*}{ Source } & \multirow[b]{2}{*}{$\begin{array}{l}\text { Isolated } \\
\text { by: }\end{array}$} & \multicolumn{2}{|c|}{ Culture routine } \\
\hline & & & & Medium & Temp. $\left({ }^{\circ} \mathrm{C}\right)$ \\
\hline Aspergillus amstelodami (Mang.) Thom and Church & - & & & MY40 & 30 \\
\hline Aspergillus candidus Link & - & & & YSA & 30 \\
\hline Aspergillus flavus Link & - & & & YSA & 30 \\
\hline Aspergillus fumigatus Fresenius & - & Indonesia. & S. Phillips & MEA & 30 \\
\hline Aspergillus penicillinoides Stegazzini & - & & & MY40 & 30 \\
\hline Aspergillus restrictus Smith & - & & & MY40 & 30 \\
\hline Aspergillus ruber Estienne & - & & & MY40 & 30 \\
\hline Botrytis sp. & - & $\begin{array}{l}\text { Little High Wood, University } \\
\text { of Durham, UK }\end{array}$ & F. M. Dewey & MEA & 25 \\
\hline Corynascus sepedonium (Emmos) v. Arx & - & & & YSA & 30 \\
\hline Eupenicillium javanicum (van Beyrna) Stolk and Scott & - & & & MEA & 30 \\
\hline Fusarium graminearum Schwabe & - & & & YSA & 30 \\
\hline Humicola lanuginosa (Griffon and Maublanc) Bunce & - & & & YSA & 45 \\
\hline Humicola insolens Cooney and Emerson & IMI 126330 & & & YSA & 45 \\
\hline Mucor pusillus Lind + & - & & & YSA & 30 \\
\hline Penicillium citrinum Thom & - & Naturally infected orain & & MEA & 30 \\
\hline Penicillium diversum var. aureum Raper and Fennel & - & Naturally iniected grain, & S. Phillips & MEA & 30 \\
\hline Penicillium islandicum Sopp & - & & & MEA & 30 \\
\hline Penicillium sp. isolate $\mathrm{X}^{*}{ }^{*}$ & - & & & MEA & 30 \\
\hline Penicillium $\mathrm{sp}$. isolate $\mathrm{XCII}^{*}$ & - & & & MEA & 30 \\
\hline Penicillium sp. isolate DFNG* & - & & & MEA & 30 \\
\hline Penicillium miczynskii Zaleski & - & & & MEA & 30 \\
\hline Penicillium purpurogenum Stoll & - & & & MEA & 30 \\
\hline Penicillium variabile Sopp & - & & & YSA & 30 \\
\hline Penicillium waksmanii & - & $\begin{array}{l}\text { Ponape, E. Caroline Islands, } \\
\text { Philippines }\end{array}$ & F. M. Dewey & MEA & 30 \\
\hline Thermomyces stellata & IMI 77024 & - & & YSA & 30 \\
\hline Trichoderma sp. & - & $\begin{array}{l}\text { Little High Wood, University } \\
\text { of Durham, UK }\end{array}$ & F. M. Dewey & MEA & 25 \\
\hline
\end{tabular}

* Three isolates of an unnamed species of Penicillium.

$\mathrm{Na}_{2} \mathrm{HPO}_{4}, 0.02 \% \mathrm{KH}_{2} \mathrm{PO}_{4}, \mathrm{pH} \mathrm{7.2)}$. To help wet the hydrophobic surface of the culture, the mycelial surface was gently stroked with a sterile plastic pipette tip. The resulting fluid, approximately $800 \mu l$ in volume, was removed by suction, placed in an Eppendorf tube and spun in a Microfuge for $2 \mathrm{~min}$ at $13250 \mathrm{~g}$ to remove cell debris, and then used immediately as the immunogen without prior concentration or freezing. This solution contained approximately $1.5 \mathrm{mg}$ protein $\mathrm{ml}^{-1}$ as determined by the Lowry method.

Three female Balb/C mice (6-week-old) were given three intraperitoneal injections of $300 \mu \mathrm{l}$ (about $500 \mu \mathrm{g}$ protein) of the immunogen at 0,2 and 8 weeks. Two mice were bled from the tail vein $5 \mathrm{~d}$ after the third injection.

Production of hybridomas. Methods for cell culture and the fusion protocol were the same as those used in preparation of mAbs to Humicola lanuginosa and Ophiostoma ulmi (Dewey et al., 1989 a,b). Cells of the myeloma cell line SP2/0-Ag14 were fused with splenocytes from an immunized mouse by suspending them in $30 \%(\mathrm{w} / \mathrm{v})$ polyethylene glycol (PEG), $M_{\mathrm{r}} 1500$, in serum-free RPMI 1640 (Flow Labs) for $7 \mathrm{~min}$ including a $2 \mathrm{~min}$ spin at $500 \mathrm{~g}$. PEG was removed by suction, the cells slowly resuspended in $5 \mathrm{ml}$ non-supplemented RPMI and finally further diluted into $45 \mathrm{ml}$ RPMI with $20 \%$ (v/v) foetal bovine serum (FBS) and plated out into ten 96-well trays at $50 \mu$ l per well. After $24 \mathrm{~h}$ $50 \mu \mathrm{l}$ of selective medium containing double-strength hypoxanthine azaserine (HAZA) (Foung et al., 1982) was added to each well. After 7 to $10 \mathrm{~d}$, wells containing clones were identified and supernatants assayed for antibodies by ELISA using wells coated with surface washings of $P$. islandicum. Selected cell lines were re-cloned, grown in bulk in non-selective medium, preserved by freezing slowly in FBS/DMSO $(92: 8, \mathrm{v} / \mathrm{v})$ and maintained in liquid nitrogen.

\section{Immunoassays}

ELISA. Screening assays used were the same as those described previously (Dewey \& Brasier, 1988). Wells were coated overnight at $4{ }^{\circ} \mathrm{C}$ with surface washings (20-fold dilution) of either $P$. islandicum or another test fungus ( $25 \mu \mathrm{g}$ protein $\left.\mathrm{ml}^{-1}\right)$ in PBS. Wells were incubated for $2 \mathrm{~h}$ with the primary antibody, $1 \mathrm{~h}$ with the secondary antibody conjugate [Sigma no. 0412; goat anti-mouse polyvalent (IgG + IgM) peroxidase conjugate diluted 200 -fold in PBST (PBS with $0.05 \%$ Tween 20)], and $30 \mathrm{~min}$ with the substrate, tetramethylbenzidene, in acetate/citrate buffer, $\mathrm{pH} 5.4$. The reaction was stopped by adding $2.5 \mathrm{M}-\mathrm{H}_{2} \mathrm{SO}_{4}$. All washings between incubations were with PBST. The $A_{450}$ was read immediately on a Titertek Miniscan or a Dynatech MR 700 Microplate Reader that had been blanked against an empty unused well. Wells were considered positive if they had absorbance readings $>3$ times the control wells. Control wells were incubated with tissue culture medium containing 5\% FBS in place of hybridoma supernatant. Each test plate contained eight control wells. Antibody and substrate incubations were all done at room temperature.

The diagnostic ELISA test used for routine testing of natural rice samples was essentially the same procedure as that above. Wells were passively coated with fungal antigens that had diffused out from infected grains soaked individually, overnight, in $150 \mu$ PBS in microtitre wells.

DIP-STICK. These assays were essentially the same as those developed for detection of $\boldsymbol{H}$. lanuginosa in rice grains (Dewey et al., $1989 a$ ). Strips, $2 \times 25 \mathrm{~mm}$, of Millipore polyvinylidene difluoride (PVDF) membrane (Immobilon II) were pre-wetted in $100 \%$ methanol followed by water. They were then placed overnight in Eppendorf tubes containing individual rice grains immersed in $200 \mu \mathrm{l}$ PBS. After 
removal, the strips were air-dried and processed collectively in Universal tubes. Strips were re-wetted in methanol and then water, blocked with a $5 \%(\mathrm{w} / \mathrm{v})$ solution of BSA in Tris-buffered saline (TBS; $20 \mathrm{~mm}$-Tris/ $\mathrm{HCl}, 0.9 \% \mathrm{NaCl}, \mathrm{pH} 8.2)$ for $30 \mathrm{~min}$, exposed to the undiluted primary antibody for $2 \mathrm{~h}$, incubated with Janssen AuroProbe (BL grade) goat anti-mouse IgG + IgM gold conjugate (diluted $1 / 100$ ) for $1 \mathrm{~h}$, treated with Janssen silver enhancer (Intense II) for a maximum of $30 \mathrm{~min}$ and finally washed in several changes of distilled water. Incubations and washings were done at room temperature on a rocking table. Washings between incubations were each $3 \times 5 \mathrm{~min}$ with TBS containing $0.1 \%$ BSA.

Immunoftuorescence. Mycelium of $P$. islandicum was grown on glass slides and fixed and immunostained by the same methods as those used by Dewey et al. (1984) to detect Phaeolus schweinitzii. Slides were airdried and fixed by immersing in ethanol/chloroform/formalin $(6: 3: 1$, by vol.) for $3 \mathrm{~min}, 95 \%$ methanol for $4 \mathrm{~min}$, rinsed briefly in distilled water and finally air-dried. Wells were incubated with $15 \mu \mathrm{l}$ of primary antibody, PI01, for $1 \mathrm{~h}$ and the secondary fluorescein-conjugated goat anti-mouse antibody (Sigma no. F-9006) for $30 \mathrm{~min}$. Slides were washed by immersing in PBS for $3 \times 5 \mathrm{~min}$ between and after incubations. Stained tissue was mounted in Citifluor PBS/glycerol mounting medium (City University, London, UK) and viewed and photographed with a Zeiss indirect fluorescence microscope.

Determination of immunoglobulin subclass. A modified ELISA test was used (Dewey et al., 1989a). mAbs were captured in wells coated overnight at $4{ }^{\circ} \mathrm{C}$ with goat anti-mouse $\mathrm{IgG}+\mathrm{IgM}$ in PBS and probed at room temperature for $1 \mathrm{~h}$ with a dilution in PBST of goat anti-mouse peroxidase conjugate specific for one of subclasses IgG1, IgG2a, IgG2b, IgG3 or IgM (Nordic isotyping subclass specific conjugate).

Characterization of $\mathrm{PIOI}$ antigen: heat and periodate treatment. Heat stability of surface antigens was tested by either heating PBS surface washings at 65,75 or $100^{\circ} \mathrm{C}$ for $5 \mathrm{~min}$ or autoclaving at 15 p.s.i. for $15 \mathrm{~min}$ and centrifuging to remove any precipitates before coating microtitre wells for ELISA tests in the usual manner.

Sensitivity of surface antigens to periodate treatment was assessed by incubating wells coated with untreated surface antigens with $20 \mathrm{~mm}$ sodium periodate in $50 \mathrm{~mm}$-acetate buffer, $\mathrm{pH} 4.5$, for $10 \mathrm{~min}, 30 \mathrm{~min}$ or 1,2 and $16 \mathrm{~h}$. Control wells were incubated with acetate buffer only. All wells were washed 5 times with PBST, 1 min each time.

Gel electrophoresis and Western blotting. Electrophoresis was done according to the method of Laemmli (1970) under denaturing conditions using $12.5 \%$ polyacrylamide slab gels with a $2.5 \%$ stacking gel. Samples for electrophoresis were prepared by washing 5 -d-old slant cultures with $1 \mathrm{ml}$ of sample buffer and centrifuging the wash to remove cell debris. Samples contained approximately 75,37 or $20 \mu \mathrm{g}$ protein in $50 \mu \mathrm{l}$ sample buffer per lane. The denaturing sample buffer contained $62.5 \mathrm{~mm}$-Tris $/ \mathrm{HCl}$, pH 6.8, $10 \%$ (w/v) sucrose, $0.002 \%$ bromophenol blue, $2 \%$ (w/v) SDS and $10 \mathrm{~mm}$-dithiothreitol. Electrophoresis was at $250 \mathrm{~V}$ for $3 \mathrm{~h}$.

Gel proteins were transferred electrophoretically, using a Janssen semi-dry blotter (JKA), onto the Millipore PVDF membrane Immobilon II at $0.8 \mathrm{~mA} \mathrm{~cm}^{-2}$ of membrane for $1 \mathrm{~h}$ with the following buffers: anode buffer $1,0.3 \mathrm{M}$-Tris in $20 \%(\mathrm{v} / \mathrm{v})$ methanol, $\mathrm{pH} 10.4$; anode buffer $2,25 \mathrm{mM}$-Tris in $20 \%(\mathrm{v} / \mathrm{v})$ methanol, $\mathrm{pH} 10 \cdot 4$; and cathode buffer, 40 mM-6-amino-n-hexanoic acid in $20 \%(\mathrm{v} / \mathrm{v})$ methanol, $\mathrm{pH} 7 \cdot 2$. The Immobilon membrane was initially wetted in methanol and then water. After transfer, membranes were either $(a)$ blocked with PBST for $30 \mathrm{~min}$ and stained for total protein by immersing in Janssen AuroDye forte for 10 to $20 \mathrm{~min}$ and washing with distilled water; (b) stained for glycoproteins using the Boehringer glycan detection kit; or (c) blocked with a $5 \%$ solution of BSA in TBS for $1 \mathrm{~h}$ and immunostained. For the latter, the membrane was incubated for $16 \mathrm{~h}$ with the mAb PI01 (undiluted tissue culture supernatant) followed by
Janssen AuroProbe (BL grade) goat anti-mouse IgG + IgM gold conjugate (diluted $1 / 100$ ) for $16 \mathrm{~h}$. The membrane was washed with TBS for $3 \times 5 \mathrm{~min}$ between treatments with primary and secondary antibody and $2 \times 5 \mathrm{~min}$ after the secondary antibody followed by $2 \times 1 \mathrm{~min}$ with distilled water. The gold stain was enhanced using the Janssen silver enhancement kit, Intense II, as described above. Membranes were agitated gently for all incubations.

\section{Results}

\section{Titre of (polyclonal) antisera}

End-point titres of antisera from the two mice were not determined but titres of antisera taken from second bleed (after three injections) were similar and very high. Absorbance values for antisera diluted 1 in 20000 tested against surface washings of $P$. islandicum diluted 20 -fold into PBS were 0.822 and 1.532 respectively. Pre-immune sera, similarly tested, gave absorbance values near those of the tissue culture medium controls (TCMCs), i.e. $0 \cdot 096$.

\section{Fusion and monoclonal antibodies}

From one fusion 120 hybridoma clones were obtained; supernatants from 20 of these cell lines tested positively for $P$. islandicum giving absorbance values of $>3 \times$ TCMC. Nine cell lines were further tested against other species of Penicillium, Botrytis and Trichoderma (Table 2) and two, PI01 and PI02, were recloned and grown in bulk. Supernatants from most cell lines were relatively non-specific: one, JDI, gave strong cross-reactions with both the Botrytis sp. and the Trichoderma sp. Four hybridoma supernatants, PI02, EH12, JDI and EE12, reacted more strongly with the Trichoderma sp. than any of the other test fungi. Preliminary testing indicated that three cell lines, EH7, PI01 and EG6, secreted speciesspecific mAbs but only one of these species-specific cell lines, PI01, proved stable. Cell lines PI01 and PI02 were recloned twice and further tested against other species of Penicillium and Aspergillus that are commonly found in stored grains. PI02, like polyclonal antisera, crossreacted with all the test fungi, whereas PI01 did not give significant cross-reactions with other storage fungi (Fig. 1).

\section{Immunoglobulin class and subclass typing}

Tests by ELISA using Nordic subclass typing conjugates indicated that PI01 was an IgG subclass 1 antibody and PI02 an IgM antibody. 
Table 2. Cross-reactivity of supernatants from nine hybridoma cell lines against antigens from different fungi as determined by ELISA

\begin{tabular}{|c|c|c|c|c|c|}
\hline \multirow[b]{2}{*}{$\mathrm{mAb}$} & \multicolumn{5}{|c|}{ Absorbance reading in ELISA } \\
\hline & P. islandicum & Botrytis sp. & $\begin{array}{c}\text { Source of antigens: } \\
\text { Trichoderma sp. }\end{array}$ & $\begin{array}{l}\text { Penicillium } \\
\text { sp. nov. }\end{array}$ & P. waksmanii \\
\hline EH7 & $3 \cdot 180$ & 0.125 & $0 \cdot 114$ & 0.172 & $0 \cdot 150$ \\
\hline PI01 & 0.745 & $0 \cdot 126$ & 0.095 & 0.043 & 0.032 \\
\hline EG6 & $1 \cdot 365$ & $0 \cdot 153$ & $0 \cdot 160$ & 0.041 & 0.029 \\
\hline PI02 & $3 \cdot 136$ & $0 \cdot 212$ & $3 \cdot 206$ & ND & ND \\
\hline EH12 & $0 \cdot 158$ & $0 \cdot 144$ & $3 \cdot 420$ & ND & ND \\
\hline JD1 & 0.735 & 0.839 & $1 \cdot 163$ & ND & ND \\
\hline EE8 & 0.211 & $0 \cdot 176$ & 0.271 & ND & ND \\
\hline $\mathrm{EE} 12$ & 0.451 & 0.482 & 0.887 & ND & ND \\
\hline EG12 & $0 \cdot 326$ & $0 \cdot 462$ & $0 \cdot 267$ & ND & ND \\
\hline TCMC & 0.049 & $0 \cdot 131$ & 0.061 & 0.056 & 0.035 \\
\hline $\mathrm{pAb}^{*}$ & $3 \cdot 107$ & $2 \cdot 810$ & $2 \cdot 690$ & $3 \cdot 336$ & $2 \cdot 369$ \\
\hline
\end{tabular}

* Polyclonal antibodies - taken from second bleed diluted 1 in 1000 in PBS.

\section{Immunofluorescence}

All hyphae of $P$. islandicum, both old and young, stained brightly with mAb PI01 but mature conidia stained only weakly (Fig. 2).

\section{Development of diagnostic assays}

ELISA. The most successful method of detecting fungal antigens in naturally infected or inoculated grains involved passive coating of microtitre wells with diffusates from grains. Grains were soaked overnight, individually in single wells containing $150 \mu \mathrm{l}$ PBS. Supernatants from one cell line, PI01, clearly distinguished grains of inoculated milled rice from control grains (Table 3) but supernatants from PI02, or polyclonal antibodies diluted 1 in 1000 , cross-reacted giving higher absorbance values with diffusates from healthy grains than from infected grains. When a sample of naturally infected grain from Indonesia was tested with PI01 by this method, approximately $90 \%$ of the grains tested positively but absorbance values were much lower than for inoculated grains. Approximately 32\% and $14 \%$ of hand-picked yellowed grains from naturally infected samples from Indonesia and the Philippines tested positively for $P$. islandicum (Table 3). 'Good' samples of white rice that did not contain yellowed grains all tested negatively.

DIP-STICK assays. Control 'good' grains and grains inoculated with Penicillium sp. isolate XCII tested negatively, and grains inoculated with $P$. islandicum were strongly positive (Fig. 3).

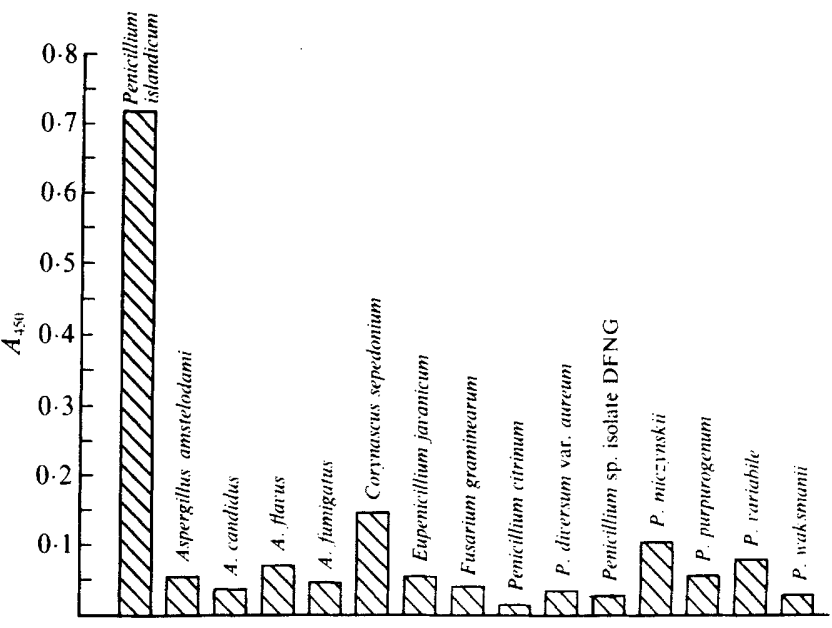

Fig. 1. Cross-reactivity of mAb PI01 against surface washings of species of Aspergillus, Penicillium, and other fungi commonly found in stored grain.

\section{Periodate and heat treatment of PI01 antigen}

When surface washings were boiled for $5 \mathrm{~min}$ before coating the ELISA wells the activity of the antigen was reduced by half but one-third of the activity still remained after autoclaving. Sodium periodate treatment of antigen-coated wells caused a slight increase in the reactivity of the wells for the first hour, but thereafter activities were reduced. Wells incubated for $16 \mathrm{~h}$ had half the activity of untreated wells (Table 4). 

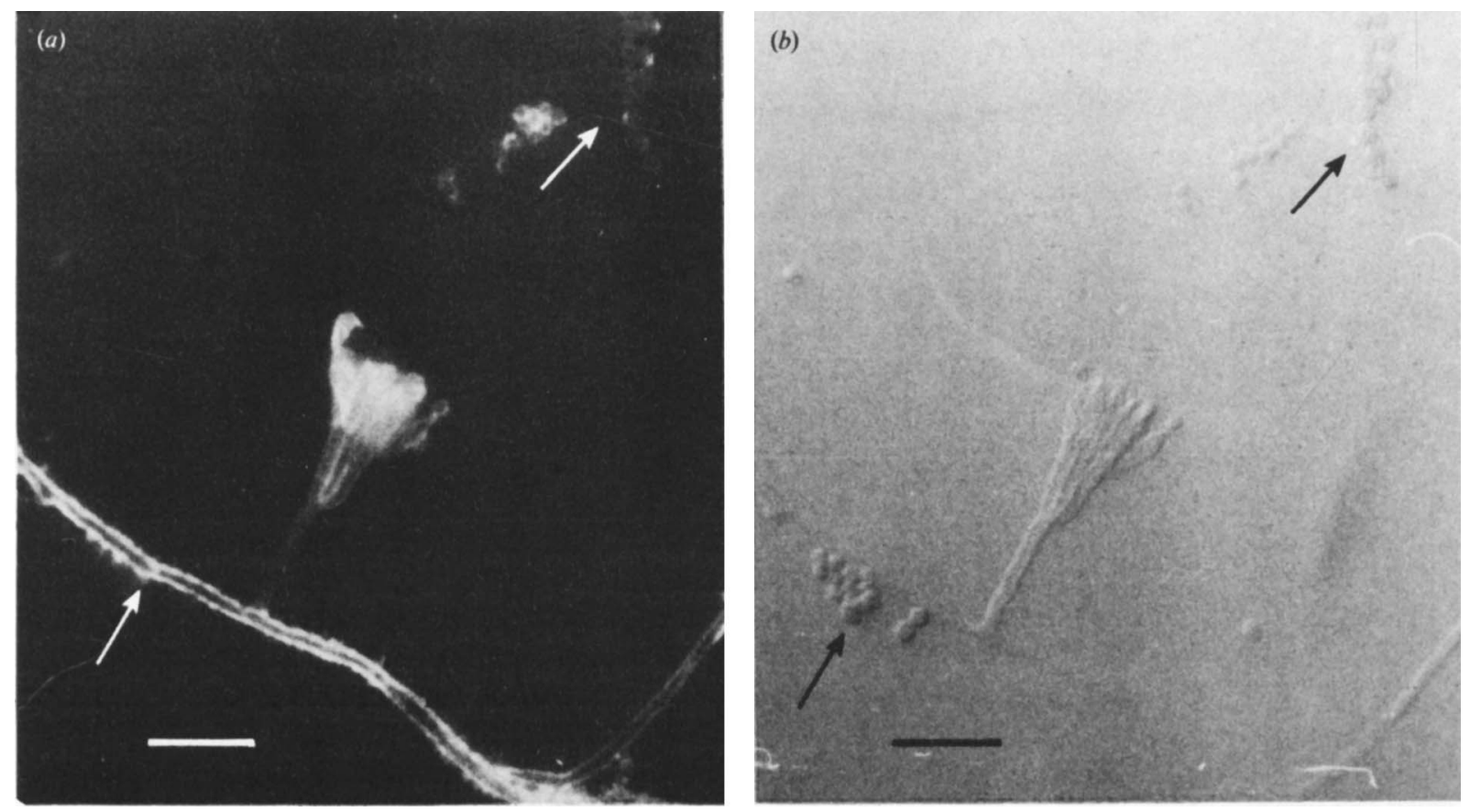

Fig. 2. (a) Immunofluorescence observed in mycelia but not conidia of cultures of $P$. islandicum grown on glass slides that were fixed and stained with the specific mAb PI01 followed by goat anti-mouse IgG/fluorescein isothiocyanate conjugate. Arrows indicate mature spores seen by white light only, i.e. not positive by immunofluorescence. (b) Same field of view observed by white light using Nomarski optics. Bars, $20 \mu \mathrm{m}$.

Table 3. Presence of P. islandicum in rice grains determined by ELISA and direct plating

\begin{tabular}{|c|c|c|c|c|}
\hline Rice sample* & Origin & $\begin{array}{l}\text { Sample } \\
\text { number }\end{array}$ & $\begin{array}{l}\text { Percentage positive } \\
\text { by ELISA }{ }^{\dagger}\end{array}$ & $\begin{array}{c}\text { Percentage infection } \\
\text { by direct plating } \ddagger\end{array}$ \\
\hline \multicolumn{5}{|l|}{ White rice } \\
\hline 'Good' & Philippines & 115 & 0 & 0 \\
\hline 'Good' & Indonesia & 20 & 0 & 0 \\
\hline Naturally infected & Indonesia & 20 & 90 & 15 \\
\hline Discoloured & Indonesia & 125 & 32 & 0 \\
\hline Discoloured & Philippines & 125 & 14 & 0 \\
\hline $\begin{array}{l}\text { Inoculated with } \\
\text { Penicillium sp. isolate XCII }\end{array}$ & Commercial & 20 & 0 & 0 \\
\hline $\begin{array}{l}\text { Inoculated with } \\
\text { Penicillium sp. isolate XD31 }\end{array}$ & Commercial & 20 & 0 & 0 \\
\hline \multicolumn{5}{|l|}{ Brown rice } \\
\hline 'Good' & Commercial & 20 & 10 & -- \\
\hline $\begin{array}{l}\text { Inoculated with } \\
P: \text { islandicum batches } 1 \\
\text { and } 13\end{array}$ & Commercial & 20 & 100 & 100 \\
\hline
\end{tabular}

* Good rice - rice dried as soon as possible after harvest; discoloured rice-yellow colour as described by Phillips et al. (1984).

$\dagger$ Samples positive by ELISA (using mAb PI01) were those with absorbance value $>3$ times the TCMC.

$\ddagger$ Percentage infection as determined by a plating-out technique (Phillips et al., 1984). 
(a)

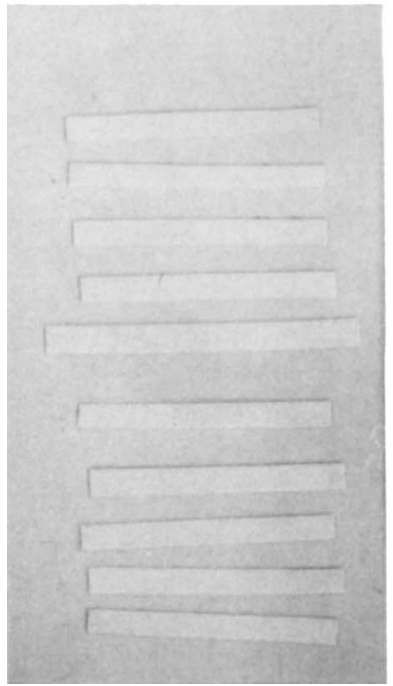

(b)

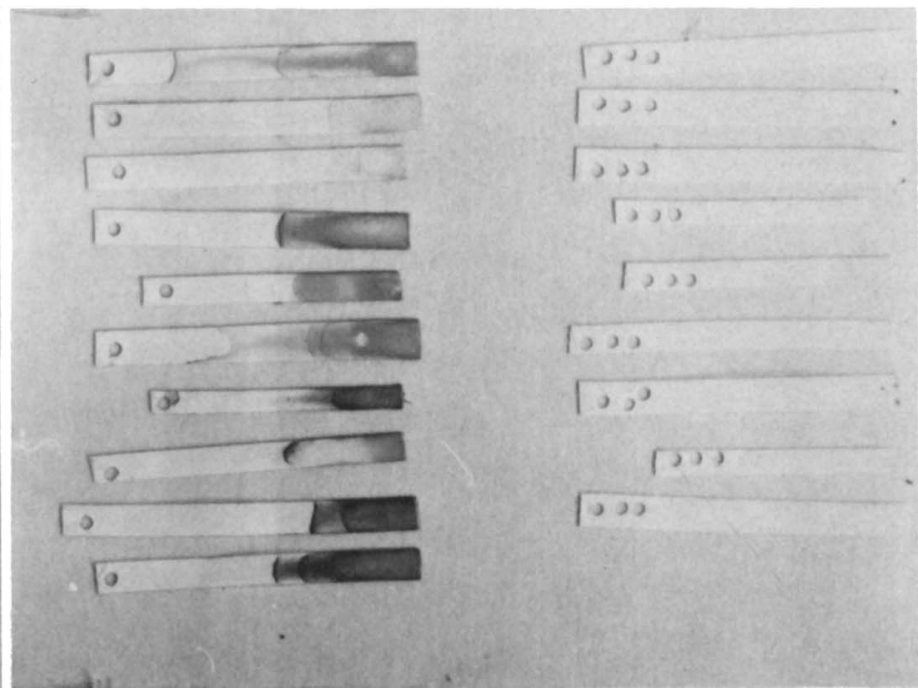

Fig. 3. DIP-STICK immunoassays of diffusates from brown rice grains probed with mAb PI01 specific for $P$. islandicum. (a) Control rice grains (not inoculated); $(b)$ rice grains inoculated with $P$. islandicum; $(c)$ rice grains inoculated with Penicillium sp. isolate XCII. Dipsticks coated with diffusates from rice grains inoculated with $P$. islandicum and processed with tissue culture medium gave negative results (not shown).

Table 4. Effect of periodate and heat treatment on the reactivity of the PIOI antigen as determined by ELISA

Results are expressed as a percentage of the absorbance values given by untreated controls.

\begin{tabular}{cclc}
\hline \hline $\begin{array}{c}20 \text { mM-Periodate } \\
\text { treatment }\end{array}$ & Reactivity & Heat treatment & Reactivity \\
\hline Control & 100 & Control & 100 \\
$10 \mathrm{~min}$ & 94 & $65^{\circ} \mathrm{C}, 5 \mathrm{~min}$ & 90 \\
$30 \mathrm{~min}$ & 107 & $75^{\circ} \mathrm{C}, 5 \mathrm{~min}$ & 65 \\
$1 \mathrm{~h}$ & 109 & $100^{\circ} \mathrm{C}, 5 \mathrm{~min}$ & 53 \\
$2 \mathrm{~h}$ & 95 & Autoclaving & 32 \\
$16 \mathrm{~h}$ & 48 & & \\
\hline \hline
\end{tabular}

\section{Gel electrophoresis and Western blotting}

In Western blots of SDS-PAGE gels of surface washings of $P$. islandicum three bands could be seen within an immunopositive and glycan-positive region (Fig. 4). The middle band corresponded approximately to the $M_{\mathrm{r}}$ 92000 marker. These bands could be seen only faintly on the blots stained for proteins. Lower $M_{\mathrm{r}}(<66000)$, nonimmunopositive peptide bands, were clearly evident on the protein blot but not on the glycoprotein or immunostained blots.

\section{Discussion}

In this study we have shown that saline surface washings of a solid culture of $P$. islandicum can be used directly, without concentration or Freund's adjuvant, both as an immunogen and as a source of antigens to screen hybridoma supernatants for species-specific mAbs. This very simple method reduces considerably the time and effort involved in raising hybridomas that secrete mAbs to fungi that are species-specific. It also provides a mechanism for raising mAbs to surface molecules that are easily removed and therefore negates lengthy extraction procedures in diagnostic assays to detect the fungus in or on its natural substrate/host. It is not known if this method can be used with all fungi that can be grown in vitro but it has been used equally successfully by us to raise a specific mAb to $H$. lanuginosa (Dewey et al., 1989a). Polonelli et al. (1986) used a similar method to raise antibodies to mycopathogens but their antigenic material was not necessarily limited to surface molecules, since they included Merthiolate in the bathing solution.

We have shown by immunofluorescence and ELISA that the species-specific mAb PI01, which is an IgG1 antibody, binds to antigens present in the hyphal wall region and in surface washings. The resistance of this antigen to heat and periodate treatment together with other evidence (Fig. 4) suggests that it is a glycoprotein with three major peptide components. These results are 


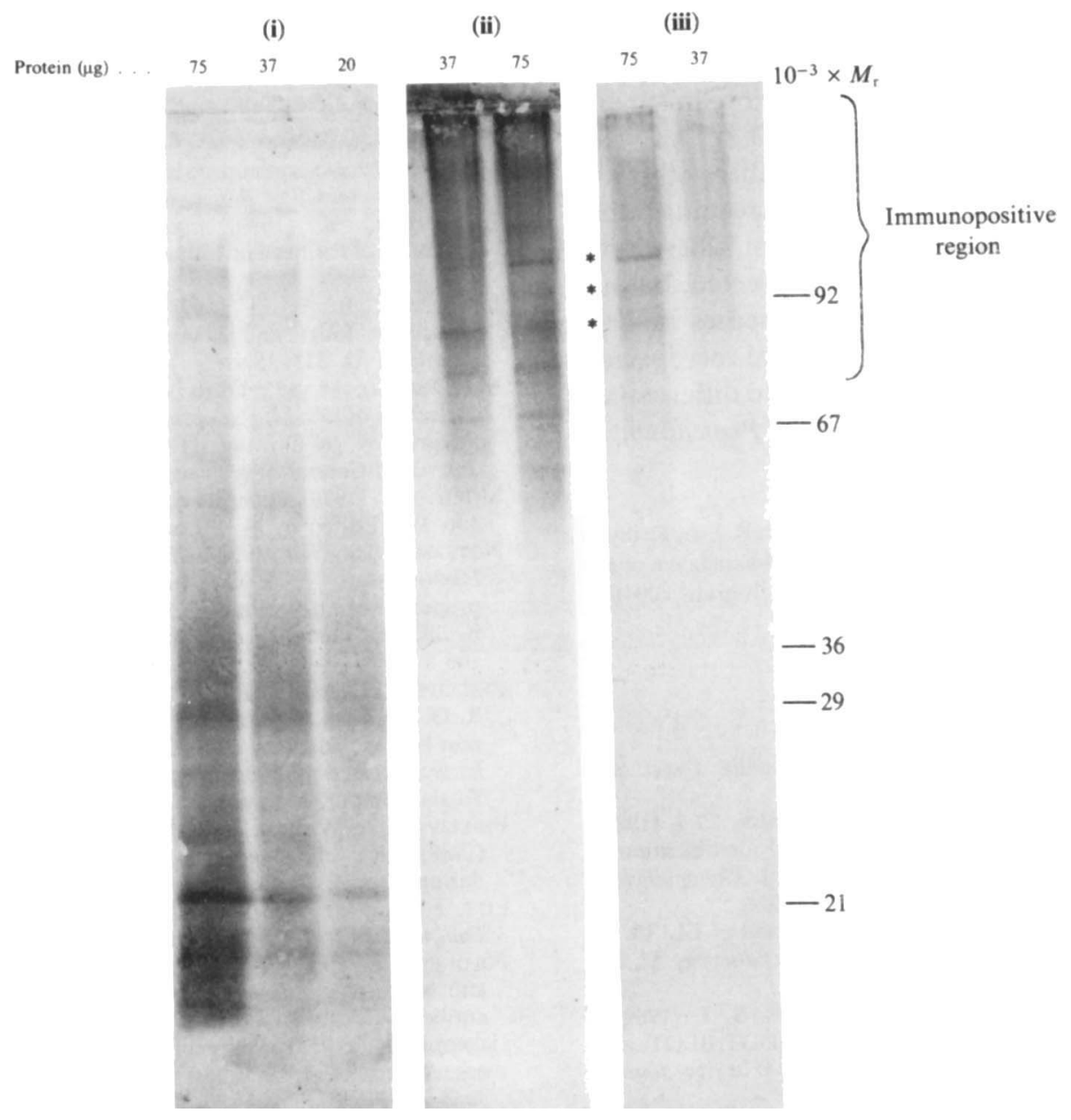

Fig. 4. Western blots of surface washings of $P$. islandicum run on $12.5 \%$ SDS-PAGE gels run under denaturing conditions. (i) Stained for total protein with Janssen AuroDye forte; (ii) stained for glycoprotein using the Boehringer glycan detection kit; (iii) immunostained with mAb PI01 (immunopositive bands are indicated by asterisks). Samples contained the amounts of protein indicated.

consistent with previous studies of HPLC fractions, that absorbed at $280 \mathrm{~nm}$, of saline washes of $P$. islandicum (MacDonald et al., 1989). The mAb PI01 recognized, by ELISA, two fractions, one of high $M_{\mathrm{r}}(>150000)$ and the other of low $M_{\mathrm{r}}$. Very little is known about the sites and nature of species-specific antigens in fungi but our results are consistent with those of Wycoff et al. (1987) and Hardham et al. (1986), who raised mAbs to extracellular glycoproteins of Phytophthora megasperma f. sp. glycinea and zoospores of Phytophthora cinnamomi, respectively. Both groups of workers found that the mAbs with the highest specificity were IgG1 antibodies. Wycoff et al. (1987) also found that those mAbs that bound to extracellular glycoproteins in ELISA tests would also bind to hyphal fragments.

$\mathrm{mAb}$ PI01 proved to be a useful tool in the detection of $P$. islandicum in rice grains and could provide a quick means of screening large batches of grain. ELISA tests enabled us to detect $P$. islandicum in grains that had not been surface sterilized. We found that estimates of the percentage of grains infected determined by ELISA were higher that those estimates obtained by conventional plating. This is to be expected since the latter method depends on surface sterilization to prevent overgrowth from spores of quick-growing contaminant fungi. Information on true mycelial growth on the surface of the grain is therefore necessarily lost when grains are surface sterilized.

Much lower ELISA values were found for naturally infected grains than for inoculated grains, Examination of these grains by eye and microscopically (data not presented) confirmed the presence of a greater quantity of fungus in the inoculated grain. Similarly, in parallel studies with grains inoculated or naturally infected with $H$. lanuginosa (Dewey et al., 1989a), considerably more fungus was detected in inoculated grains. 
The strong binding of PI01 to mycelia but not to mature conidia means that assays employing this $\mathrm{mAb}$ can be used to detect active growth of the organism and differentiate it from the mere presence of spores. This will enable quick screening of large numbers of grains samples. It would also be useful for screening other xerophilic environments, such as house dust, where miteassociated growth of the organism is suspected, but not proven, of being involved in allergic diseases such as asthma (Lustgraaf, 1978). The potential of speciesspecific assays such as this one to detect and differentiate any one of the numerous species of Penicillium is enormous.

The authors acknowledge valuable discussions with P. J. A. Reilly in the preparation of this manuscript and the financial assistance of the UK Overseas Development Administration (research grant x0046).

\section{References}

CoOney, D. G. \& Emmerson, R. (1964). Thermophilic Fungi. San Fransisco: W. H. Freeman.

Dewey, F. M., Barrett, D. K., Vose, I. R. \& Lamb, C. J. (1984). Immunofluorescent microscopy for detection and identification of propagules of Phaeolus schweinitzii in infested soil. Phytopathology 74, 291-296.

DeWEY, F. M. \& BRASIER, C. M. (1988). Development of ELISA for Ophiostoma ulmi using antigen coated wells. Plant Pathology 37, 2835.

Dewey, F. M., MacDonald, M. M. \& Phillips, S. I. (1989a). Development of monoclonal-antibody-ELISA, -DOT-BLOT and -DIP-STICK immunoassays for Humicola lanuginosa in rice. Journal of General Microbiology 135, 361-374.

Dewey, F. M., Munday, C. J. \& Brasier, C. M. (1989 $b$ ). Monoclonal antibodies to components of the Dutch Elm pathogen Ophiostoma ulmi. Plant Pathology 38, 9-20.

Foung, S. K. H., Sasaki, D. T., Grumet, F. C. \& Engleman, E. C. (1982). Production of functional human T-T hybridomas in selection medium lacking aminopterin and thymidine. Proceedings of the National Academy of Sciences of the United States of America 79, 7484-7488.

Hardham, A. R., Suzaki, E. \& Perkin, J. L. (1986). Monoclonal antibodies to isolate-, species-, and genus-specific components on the surface of zoospores and cysts of the fungus Phytophthora cinnamomi. Canadian Journal of Botany 64, 311-321.

LAEMmLI, U. K. (1970). Cleavage of structural proteins during assembly of the head of bacteriophage T4. Nature, London 227, 680 685.

LUSTGRAAF, B. V. D. (1978). Ecological relationships between xerophilic fungi and house-dust mites (Acarda pyroglyphidae). Oecologia 33, 351-359.

MacDonald, M. M., Dunstan, R. H. \& Dewey, F. M. (1989). Detection of low- $M_{\mathrm{r}}$ glycoproteins in surface washes of some fungal cultures by gel-filtration HPLC and by monoclonal antibodies. Journal of General Microbiology 135, 375-383.

MOREAU, C. (1979). Islanditoxicosis. In Moulds, Toxins and Food, pp. 190-196. Edited by M. Moss. Chichester: John Wiley.

Notermans, S., Wieten, G., Engel, H. W. B., Rambouts, R. M., Hoogerhout, P. \& van BoOM, J. H. (1987). Purification and properties of extra-cellular polysaccharide (EPS) antigens produced by different mould species. Journal of Applied Bacteriology 62, 157 166.

Phillips, S. I., Mitfa, R., Snitha, S., Wallbridge, A. J., Cooke, R. D. \& BAKER, A. A. (1984). A study of the factors involved in the post-harvest yellowing of rice. In Health and Ecology in Grain Postharvest Technology, Proceedings of the 7th ASEAN Technical Seminar, Kuala Lumpur, Malaysia.

Phillips, S. I., Widjaja, S., Wallbridge, A. J. \& CoOKe, R. D. C (1988). Rice yellowing during post harvest drying by aeration and during storage. Journal of Stored Products Research 24, 173-181.

PITT, J. I. (1979). The Genus Penicillium and its Teleomorphic States Eupenicillium and Telaromyces. London: Academic Press.

Polonelli, L., Castagnola, M. \& Morace, G. (1986). Identification and serotyping of Microsporum canis isolates by monoclonal antibodies. Journal of Clinical Microbiology 23, 609-615.

TsuNODA, H. (1953). Study of damage of stored rice, caused by microrganisms. II. On yellow rice from Thailand. Transactions of the Japanese Phytopathology Society 13, 3.

WyCOFF, K. L., Jellison, J. \& AyeRs, A. R. (1987). Monoclonal antibodies to glycoprotein antigens of a fungal plant pathogen, Phytophthora megasperma f. sp. glycinea. Plant Physiology 85, 508515. 